\title{
Evaluation of eight varieties of cowpea (Vigna unguiculata (L.) Walp) in Asaba agro-ecological environment, Delta State, Nigeria
}

\author{
${ }^{1 *}$ Agbogidi, O. M. and ${ }^{1}$ Egho, E.O.
}

\section{Abstract}

A study was conducted during the early planting season of 2011 at Asaba, Delta State, Nigeria to evaluate eight varieties of cowpea (IT80D-699, IT82 (e-18), Ife Brown, IT870-9411 and TVX3236, IT90K-277-2, IT870-9411 and IT828-146) for adaptation in the altisol of Asaba agro ecological zone with a view to recommending the suitable varieties to farmers in the area for planting. The results showed that significant differences $(\mathrm{P} \leq 0.05)$ existed among the varieties tested in all the growth characters measured. Ife Brown, IT8482246-4 and TVX3236 varieties performed significantly better both in the growth and yield as well as yield related parameters when compared to IT800D-699, IT82(e-18), IT870-9411 and IT828-146 varieties. This study hereby recommends Ife Brown, IT848-2246-4 and TVX3236 varieties which performed appreciably better to farmers in Asaba agro ecological zone for planting.

Key words: Cowpea varieties, growth, yield parameters, Asaba, Nigeria.

\section{Introduction}

Cowpea is a dicotyledonous plant belonging to the family Fabaceae and sub-family, Fabiodeae. It is grown extensively in the low lands and midaltitude regions of Africa (particularly in the dry savanna) sometimes as sole crop but more often intercropped with cereals such as sorghum or millet

${ }^{1}$ Faculty of Agriculture,

Delta State University, Asaba Campus

*omaghogidi@yahoo.com, 07038679939 and Corresponding Author 
(Agbogidi, 2010a). World production of cowpea was estimated to be 2.27 million tons of which Nigeria produces about 850,000 tones (FAO, 2002; Adaji et al., 2007). Cowpea is of major importance to the livelihoods of millions of relatively poor people in less developed countries of the tropics (FAO, 2002). Islam et al. (2006) emphasized that all parts of the plant used as food are nutritious providing protein and vitamins, immature pods and peas are used as vegetables while several snacks and main dishes are prepared from the grains (Duke, 1981; Bittenbender et al., 1984). Egho (2009) reported that Nigeria is the $2^{\text {nd }}$ greatest consumer of cowpea in the whole world. Among the legumes, cowpea is the most extensively grown, distributed and traded food crop consumed, more than 50\% (Philips and McWalters, 1991; Ogbo, 2009: Agbogidi, 2010a). This is because the crop is of considerable nutritional and health value to man and livestock (Agbogidi, 2010b). They form a major staple in the diet in Africa and Asian continents (Awe, 2008). The seeds make up the largest contributor to the over all protein intake of several rural and urban families hence Agbogidi (2010b) regarded cowpea as the poor man's major source of protein. Their amino acid complements those of cereals (Fashokin and Ojo, 1988; Fashokin andFansaya, 1988; Asumugha, 2002). Their mineral contents: calcium and iron are higher than that of meat, fish and egg and the iron content equates that of milk; the vitamins- thiamin, riboflavin, niacin (water soluble) and their levels compare with that found in lean meat and fish (Platt, 1962; Adams, 1984; Rachie et al., 1985; Achuba, 2006) which make them very useful in blood cholesterol reduction (Johnson et al., 1983; Anderson, 1985). Many researchers including Anderson (1983), Adaji et al. (2007) and Adeniji (2007) have showed that daily consumption of $100-135 \mathrm{gm}$ of dry beans reduces serum cholesterol level by $20 \%$ thereby, reducing the risk for coronary heart diseases by 40\% (Anderson, 1985; Ofuya, 1993). Besides its health related benefits, beans are inexpensive, considerably cheaper than rice or any other dietary fibre type (Ayenlere et al., 2012). It is a good food security item as it mixes well with other recipe (Singh and Rachie, 1985; Muoneke et al., 2012). Cowpea fixes atmosphere nitrogen through symbiosis with nodule bacteria (Shiringani and Shimeles, 2011). It does well and most popular in the semiarid of the tropics where other food legumes do not perform well (Sankie et al., 2012). It is an extremely resilient crop and cultivated under some of the most extreme agricultural conditions in the world (Owolade et al., 2006; Muoneke et al., 2012).

In Nigeria cowpea is majorly produced in the North in the savannah belt. Its yield in the South is affected by some environmental factors including 
rainfall hence it is seasonal. The high demand for this leguminous multipurpose crop plant is not met in the Southern part of Nigeria. The production of cowpea all year round basis in all parts of Nigeria is expected to boost production, thereby improving nutrition, contributes to food security as well as increase revenue of the producers and creates employment opportunities and enhancing the efficiency of utilization of labour. It is against this background that a study as this has been undertaken to evaluate eight varieties of cowpea in altisol (Asaba agro-ecological environment with a view to selecting the variety (ies) that will best adapt to the conditions in the Southern part of Nigeria using Asaba agro-ecological environment as case study.

\section{Materials and Methods}

Study Area - The experiment was conducted at the Teaching and Research Farm of the Agronomy Department, Delta State University, Asaba Campus between May and August, 2011. Asaba is located at $06^{\circ} \mathrm{C} 14$ 'N, longitude $06^{\circ} 49^{\prime} \mathrm{E}$, temperature: $28 \pm 6^{\circ} \mathrm{C}$, rainfall: $1500-1849 \mathrm{~mm}$, relative humidity: $77.2-80 \%$ and sun shine: 4.8 hours (Asaba Meteorological Station, 2010).

\section{Pre-planting soil analysis}

Soil samples from the study area were analysed prior to experimentation after collection with the aid of auger from each block. The samples were bulked and air-dried at room temperature of between 25 and $27^{\circ} \mathrm{C}$ for five days, crushed to pass through a $2 \mathrm{~mm}$ sieve before they were neatly packed in a properly labeled air tight polythene bags for physio-chemical analysis at the National Institute for Oil Research (NIFOR) near Benin-City, Edo State using the standard methods. Data collected were subjected to analysis of variance (ANOVA) while significant means were separated with the Duncan's multiple range tests using SAS (2005).

Source of plant materials: The eight varieties of cowpea: IT80D-699, IT82 (e-18), Ife Brown, IT848-2246-2, TVX3236, IT90K-277-2, 17870-941-1 and IT828-146 were purchased as a single batch from IITA, Ibadan, Oyo State, Nigeria.

Procedure and experimental design: The land was ploughed with a tractor and harrowed after one week. The layout was marked using tape, pegs and ropes. The plots measured $5 \mathrm{~m}$ in length and $3 \mathrm{~m}$ in width. Spacing between plots was $1.5 \mathrm{~m}$ and planting spacing was $60 \mathrm{~cm} \times 30 \mathrm{~cm}$ following the procedure of Reminson et al. (1980). Two seeds of cowpea from each variety were planted per hole in May (early cropping season). Thinning of seedlings to one stand per hole was done at 10 days after emergence. Each plot 
consisted of 6 rows of 36 cowpea stands per row. The experimental area was hoe-weeded regularly before maturity to enable the plants develops under non-limiting condition. Insect pests were controlled with Karate 2.5EC at 2 weeks after seedling emergence and thereafter, at 10 days' intervals following the procedure of Reminson et al. (1980) and Awe (2008). The experiment was laid down in a randomized complete block design (RCBD), with four replications while subsequent examination followed. Growth parameters measured were plant height, leaf area, number of leaves, stem diameter and yield and yield related parameters. The plant height was measured using measuring tape from soil level to terminal bud at two weeks interval after transplanting, number of leaves was determined by visual counting of the number of leaves for each seedlings per variety, leaf area measurement was achieved was by tracing the leaves on a graph paper and the total area per plant was obtained by measuring the maximum leaf and the length and breadth of the leaf was multiplied by the correction factor 0.75 following the formula of (Agbogidi and Ofuoku., 2005), collar diameter was measured using veneer caliper every two weeks. Other parameters measured were 100 seed weight, number of pods per plant, pod length, number of seeds per pod, pod load, and dry grains yield $\left(\mathrm{kgha}^{-1}\right) .100$ seed weight yield were weighed with triple bean balance (Haus Model) and extrapolated to hectares. Number pods per plant were determined following the method of Egho (2009). One meter length of cowpea row was taken with 1 meter ruler. The length was marked with 2 sticks and the pods and plants that fell within this distance were counted. The number of pods was then divided by the number of cowpea plants.

$\underline{\text { Number of pods }}=$ No. of pods per plant

Number of plants

At maturity, that is, at about 65 - 70 days after planting (DAP), pods were harvested with hand, sun dried for one week and later shelled. The dry grain yields in each plot were weighted and recorded. One hundred seeds were picked from the grains in each plot and weighed. Pod load was assessed in the field by visual rating on a scale of $1-9$ following the procedure of Egho (2009). It was done by rating the scale from the two central rows of each plot. Assessment was done in the field at 60 days after planting when pods were fully filled and matured but still green. Data collected were exposed to analysis of variance (ANOVA) while significant means were separated with the Duncan's multiple range tests using SAS (2005). 


\section{Results and Discussion}

The initial pre-planting soil properties of the area under study are shown in Table 1. Generally, the results of the pre-planting soil analysis showed that the soil is marginally fertile which implies that the soil is low in $\mathrm{N}$ content, organic matter, available phosphorus exchangeable bases and exchangeable cations following Federal Ministry of Agriculture and Natural Resources (FMANR, 1990). This further implies that the soil is poor in nutrients and of low productivity therefore, response to organic manure would be encouraged (Table 1). The observed 6.20 value of the $\mathrm{pH}$ of the soil indicate $\mathrm{s}$ that the soil is slightly acidic and this can be attributed to the high rainfall prevalent in the area leading to leaching of the basic cations from the surface area of the soil. The low organic matter content and total nitrogen could be attributed to the effects of soil erosion, leaching and bush burning predominant in the study area. Similarly, the low exchangeable cations may be due to the low clay activity and low organic content of the soil. The CEC was average (15.20 $\mathrm{cmol} / \mathrm{kg}-1$ ) while the base saturation indicates that the study area has low fertility stat us which may be due to the long usage of the area for serious cropping without replenishing the lost nutrients through fertilizer application. The results of the pre-planting soil analysis agree with the findings of Enwezor et al. (1991) and Egbuchua (2007). The soil is sandy loam in texture with characteristics of $84.60 \%$ sand, $6.92 \%$ silt and $8.48 \%$ clay. The result of the soil experimental site confirms to the findings of Egbuchua (2007) on the nutrient status of Anwai/Asaba soil. This observation could be as a result of basic macronutrients such as $\mathrm{N}, \mathrm{P}, \mathrm{K}, \mathrm{Ca}, \mathrm{Mg}, \mathrm{S}$ and the biological production of acid which limits plant growth and development (Agbogidi et al., 2006; Agbogidi and Okonmah,2011a; Agbogidi and Okonmah,2011b).

The performance of the various varieties of cowpea in terms of plant height, number of leaves, leaf area, stem diameter and yield and yield components are presented in Table 2, 3, 4 and 5 respectively. Significant differences at the $5 \%$ probability level were observed in all the varieties of cowpea studied with Ife Brown, IT848 - 2246-4 and TVS3236 performing significantly better in all the growth and yield characters measured when compared to the other varieties. For example, for number of seeds per pod, TVS3236 had value of 8.2; IT848-2246-4 had 7.8 while Ife Brown produced 7.0 seeds. These were significantly $(\mathrm{P} \leq 0.05)$ higher than IT870-9411, IT80D-699 and IT828-146 that had 4.8, 4.0 and 3.8 seeds respectively. Similarly, IT848-2246-4 had the highest dry grain yield (biomass production $148.7 \mathrm{kgha}^{-1}$ which was significantly $(\mathrm{P} \leq 0.05)$ higher than Ife Brown (146.5) and TVX3236 (126.3). These three varieties had appreciable yield 
accumulation when compared to IT828-246 and IT80D-699 varieties that produced as low as 29.1 and $28.4 \mathrm{kgha}^{-1}$ respectively (Table 6). The observed significant performance in Ife Brown, IT848-2246-4 and TVX32-36 show variable differences in the anatomical, morphological and physiological structures which made these varieties readily able to absorb nutrients and water from the soil, carried out effective photosynthetic process and able to store photosynthates which other varieties like IT80D-699 and IT828-146 could not do. This observation supports the earlier reports of Agbogidi and Ofuoku (2005) that plants respond differently to environmental factors based on their genetic make up and their adaptation capability indicating that variability among species.

\section{Conclusion}

This study evaluated the performance of eight varieties of cowpea in Asaba agro-ecological environment in terms of plant height, number of leaves, leaf area and yield and yield components. The results show that Ife Brown, IT848-2246-4 and TVX3236 differed significantly $(\mathrm{P} \leq 0.05)$ in their performance when compared to the other varieties especially IT828-146 and IT80D-699 that had the lowest values for all parameters assessed. Ife Brown, IT848-2246-4 and TV3236 had the highest yields over the others hence they are recommended to farmers in Asaba agro-ecological environment for cultivation.

Table 1. Physio-chemical properties of soil before experimentation

\begin{tabular}{|c|c|}
\hline Parameters & Values \\
\hline Sand (\%) & 94.5 \\
\hline Silt $(\%)$ & 2.1 \\
\hline Clay $(\%)$ & 3.4 \\
\hline Soil pH & 5.60 \\
\hline Textural class & Sandy loam \\
\hline Organic carbon $(\%)$ & 0.91 \\
\hline Organic matter (gkg-1) & 2.64 \\
\hline Total N (\%) & 0.06 \\
\hline Available p (mg/kg) & 30.00 \\
\hline $\mathrm{Ca}^{2+}(\mathrm{cmol} / \mathrm{kg})$ & 331.31 \\
\hline $\mathrm{Mg}^{2+}(\mathrm{cmol} / \mathrm{kg})$ & 0.16 \\
\hline $\mathrm{Na}^{+}(\mathrm{cmol} / \mathrm{kg})$ & 0.25 \\
\hline $\mathrm{K}^{+}(\mathrm{cmol} / \mathrm{kg})$ & 0.17 \\
\hline $\mathrm{H}^{+}(\mathrm{cmol} / \mathrm{kg})$ & 0.45 \\
\hline $\mathrm{Al}^{3+}(\mathrm{cmol} / \mathrm{kg})$ & 0.08 \\
\hline $\operatorname{ECEC~}(\mathrm{cmol} / \mathrm{kg})$ & 2.42 \\
\hline Base saturation (\%) & 78.10 \\
\hline
\end{tabular}


Table2. Plant height of cowpea as influenced by varietal differences

\begin{tabular}{lcccccc}
\hline $\begin{array}{l}\text { Cowpea } \\
\text { Variety }\end{array}$ & $\mathbf{3}$ & $\mathbf{5}$ & $\mathbf{7}$ & $\mathbf{9}$ & $\mathbf{1 1}$ & Means \\
& & & & & & $23.94 \mathrm{c}$ \\
IT 80D-699 & 19.1 & 22.6 & 24.3 & 26.7 & 27.0 & $23.06 \mathrm{~d}$ \\
IT 82(e-18) & 18.7 & 21.7 & 23.4 & 25.6 & 25.9 & $29.44 \mathrm{a}$ \\
Ife Brown (SL) & 22.6 & 28.6 & 30.1 & 32.0 & 33.9 & $28.76 \mathrm{~b}$ \\
IT 848-2246-2 & 23.2 & 27.6 & 28.7 & 31.6 & 32.7 & $28.92 \mathrm{~b}$ \\
TVx3236 & 29.6 & 28.2 & 29.0 & 30.9 & 31.9 & $22.46 \mathrm{c}$ \\
IT 90k-277-2 & 20.3 & 21.9 & 24.3 & 25.0 & 25.8 & $18.6 \mathrm{~d}$ \\
IT 870-9411 & 18.6 & 19.7 & 22.4 & 23.7 & 24.6 & \\
IT 828-146 & 14.3 & 15.6 & 19.8 & 21.6 & 22.1 &
\end{tabular}

Means with different letters are significantly different $(\mathrm{p} \leq 0.05)$ with the Duncan's multiple range tests

Table 3. Number of leaves of Vigna unguiculata as affected by varietal differences

\begin{tabular}{lllllll}
\hline Cowpea & \multicolumn{7}{c}{ Number of leaves/WAP } & $\mathbf{1}$ & Means \\
varieties & $\mathbf{3}$ & $\mathbf{5}$ & $\mathbf{7}$ & $\mathbf{9}$ & $\mathbf{1 1}$ & $7.28 \mathrm{~b}$ \\
IT 80D-699 & 5.3 & 5.4 & 7.9 & 8.8 & 9.0 & $6.70 \mathrm{c}$ \\
\hline IT 82(e-18) & 5.4 & 5.6 & 6.8 & 7.1 & 8.6 & $8.96 \mathrm{a}$ \\
Ife Brown & 6.9 & 7.9 & 8.7 & 9.6 & 11.7 & $8.94 \mathrm{a}$ \\
IT 848-2246-2 & 6.7 & 7.2 & 9.6 & 9.9 & 11.3 & $8.72 \mathrm{a}$ \\
TV x32-36 & 6.8 & 7.7 & 8.8 & 9.4 & 10.9 & $7.24 \mathrm{~b}$ \\
IT 90k-277-2 & 6.2 & 6.8 & 7.1 & 7.9 & 8.2 & $6.52 \mathrm{c}$ \\
IT 870-9411 & 5.2 & 5.8 & 6.8 & 7.0 & 7.8 & $6.42 \mathrm{c}$ \\
IT 828-146 & 5.0 & 5.7 & 6.6 & 7.2 & 7.6 &
\end{tabular}

Means with different letters are significantly different $(\mathrm{p} \leq \underline{0.05)}$ with the Duncan's multiple range tests

Table 4. Leaf area of Vigna unguiculata influenced by varietal differences

\begin{tabular}{lcccccc}
\hline $\begin{array}{l}\text { Cowpea } \\
\text { varieties }\end{array}$ & $\mathbf{3}$ & $\mathbf{5}$ & $\mathbf{7}$ & $\mathbf{9}$ & $\mathbf{1 1}$ & Means \\
\hline IT 80D-699 & 24.4 & 30.7 & 35.6 & 42.0 & 68.7 & $40.32 \mathrm{e}$ \\
IT 82(e-18) & 36.1 & 38.4 & 40.1 & 41.6 & 60.3 & $43.3 \mathrm{~d}$ \\
Ife Brown & 46.2 & 58.7 & 67.3 & 80.4 & 12.7 & $74.66 \mathrm{a}$ \\
IT 848-2246-2 & 46.7 & 62.6 & 74.4 & 76.2 & 100.8 & $72.14 \mathrm{~b}$ \\
TVx3236 & 50.4 & 56.4 & 67.4 & 75.6 & 11.6 & $72.08 \mathrm{~b}$ \\
IT 90k-277-2 & 30.2 & 42.1 & 48.7 & 56.7 & 69.8 & $49.50 \mathrm{c}$ \\
IT 870-9411 & 29.3 & 38.1 & 42.8 & 50.2 & 53.7 & $42.82 \mathrm{~d}$ \\
IT 828-146 & 28.8 & 37.0 & 40.3 & 48.7 & 49.9 & $40.94 \mathrm{e}$ \\
\end{tabular}

Means with different letters are significantly different $(\mathrm{p} \leq 0.05)$ with the Duncan's multiple range tests 
Table 5. Stem diameter of Vigna unguiculata as affected by varietal differences

\begin{tabular}{lccllll}
\hline Cowpea & Stem diameter/WAP & & & \\
varieties & 3 & 5 & 7 & 9 & 11 & Means \\
\hline IT 80d-699 & 1.1 & 1.2 & 1.4 & 1.5 & 1.6 & $1.36 \mathrm{~b}$ \\
IT 82(e-18) & 1.2 & 1.3 & 1.4 & 1.5 & 1.6 & $1.40 \mathrm{~b}$ \\
Ife Brown & 1.6 & 1.7 & 1.9 & 2.1 & 2.3 & $1.92 \mathrm{a}$ \\
IT 848-2246-2 & 1.5 & 1.6 & 1.8 & 2.2 & 2.4 & $1.90 \mathrm{a}$ \\
Tvx32-36 & 1.4 & 1.8 & 1.9 & 2.3 & 2.4 & $1.96 \mathrm{a}$ \\
IT 90k-277-2 & 1.2 & 1.3 & 1.3 & 1.4 & 1.5 & $1.34 \mathrm{~b}$ \\
IT 870-9411 & 0.9 & 1.0 & 1.0 & 1.2 & 1.3 & $1.08 \mathrm{c}$ \\
IT 828-146 & 0.8 & 1.0 & 1.1 & 1.2 & 1.3 & $1.08 \mathrm{c}$
\end{tabular}

Means with different letters are significantly different $(\mathrm{p} \leq 0.05)$ with the Duncan's multiple range tests

\section{References}

Achuba, F. I. (2006). The effect of subletethal concentration of crude oil on the growth and metabolism of cowpea (Vigna unguiculata) seedlings. The Environmentalist 21(1):17 - 20.

Adaji, M. J., Olufala O. O., Aliyu L. (2007). Effect of intra-row spacing and stand density on the growth and

yield of cowpea (Vigna unguculata (L.) Walp). In: Olulaja, O. O., Omokore, D.F., Akpa, G. N. and

Sanni, S. A. (eds.). Proceedings of the $41^{\text {st }}$ Annual Conference of the Agricultural Society of Nigeria

(ASN) held at the Institute for Agricultural Research, Samaru, Ahmadu Bello University, Zaria

between $22^{\text {nd }}$ and $26^{\text {th }}$ October, 2007. Pp $153-157$.

Adams, M. W. (1984). Cowpea production constraint and national programmes. Bean/Cowpea

Collaboration Research Support Programme. Michigan State University, East Lansing. U.S. A.

Agbato, S. O. (2003). Principle and practice of crop production. Odumatt Press Publishers,

Ibadan. Pp. $57-62$.

Agbogidi, O.M. (2009). Yield components of six cultivars of cowpea (Vigna unguiculata (L.) Walp grown on soil contaminated with spent engine oil. Acta Agronomica Nigeriana 9 (1 and 2): 1-6. 
Agbogidi, O. M. (2010a). Screening six ciltivars of cowpea (Vigna unguiculata (L.) Walp) for adaptation to soil contaminated with spent engine oil Journal of Environmental Chemistry and Ecoloxicology. 7: 103 - 109.

Agbogidi, O.M. (2010b). Response of six cultivars of cowpea (Vigna unguiculata (L.) Walp.) to spent engine oil. African Journal of Food Science and Technology 1(6):139-142.

Agbogidi, O. M., Nweke, F. U. (2008). Screening five cultivars of soya bean (Glycine max (L)

Merr.) for adaptation in soils contaminated with crude oil. Proceedings of the $40^{\text {th }}$ Annual Conference of the Agricultural Society of Nigeria held at the University of Agriculture, Umudike, Abia State, and $16^{\text {th }}-290^{\text {th }}$ Ocobter, 2006. Pp. $570-572$.

Agbogidi, O. M., Akparobi, S. O. and Eruotor, P. G. (2006). Yields of maize (Zea mays L.) as affected by crude oil contaminated soil. American journal of Plant Physiology 1(2): $193-198$.

Agbogidi, O.M. and Ofuoku, A.U. (2005). Response of sour sop (Annona muricata Linn) to crude oil levels. Journal of Sustainable Tropical Agricultural Research. 16:98-102.

Agbogidi, O. M. and Okonmah, L. U. (2011a). Performance of sweet pepper (Capsicum annuum L.) as

influenced by weeding frequency. International Journal of Science and Nature 2(4): 119-122.

Agbogidi, O. M. and Okonmah, L. U. (2011b). Effect of different spacing on the growth and yield of

cowpea (Vigna unguiculata (L) Walp) in Asaba, Nigeria. Biological and Environmental

Sciences Journal for the Tropics 8(4): $37-40$.

Agbogidi, O. M. and Okonmah, L. U. (2012). Growth and yield of maize (Zea mays L.) as

influenced by organic manure types in a Niger Delta environment. International Journal of

Agricultural Research and Development 15 (1): 818 - 824.

Anderson, J.W. (1985).Cholesterol lowering effects of canned beans for hypercholestrolmic Medical

Clinical Resources 33(4):871-875.

Asaba Meteorological Station (2009). In: Meteorological Bulletin Lagos (2009). 
Asumugha, V. U. (2002). Sensory and functional properties of dry vegetable cowpea product $26^{\text {th }}$

(Akara). In: Ubbanu, C. N., Eke, O. S. and Uzomah, A. (eds.). Proceedings of the Annual Conference of the Nigerian Institute of Food Science and Technology (NIFST)

held at the Federal University of Technology, Owerri, Imo State between $4^{\text {th }}$ and $8^{\text {th }}$ of November, 2002. Pp. $66-67$.

Awe, O. A. (2008). Preliminary evaluation of three Asian yards long bean cowpea lines in Ibadan, Southern western Nigeria. In: Proceedings of the $42^{\text {nd }}$ Annual Conference ofASN held at Ebonyi State University, Abakaliki, Nigeria between $19^{\text {th }}$ and $23^{\text {rd }}$ of October, 2008. Pp. $246-249$. Ayenlere, A. E., Mohammed, A. B., Dutse, F., Abdullahi, M. and Mohammed-Lawal, A. (2012). An assessment of the economics of maize-cowpea cropping system in Ogun area of Kwara State, Nigeria Biological and Environmental Sciences Journal for the Tropics 9(1): 39-43

Bittenbender, H. C., Barret, R. P. and Indire-Lauvsa, B. M. (1984). Beans and cowpeas as leaf vegetables and grains legumes. Monograph No. 1 Bean/Cowpea Collaborative Research Support Programme. Michigan State University, East Lansing.

Duke, J. A. (1981). Vigna uniguiculata (L.) Walp spp. unguiculata. In: Okeson, O. N. (ed.). Legumes of world importance. Plenum Press, New York. Pp. $303-305$.

Egbuchua, C. N. (2007). Pedogenetic characterization and evaluation of some wetland soils in Delta State. Ph D Thesis of Delta State University, Asaba Campus.

Egho, E. O. (2009). Control of major insect pests of cowpea (Vigna unguiculata (L.) Walp using conventional and non-conventional chemicals. A PhD Thesis submitted to the Department of Agronomy, Delta State University, Asaba Campus. 224p.

Enwezor, W. O., Ohiri, A. O., Opuwaribo, E. E. and Udo, E. J. (1991). A literature review of soil fertility investigation in Nigeria. FMA and NR, Lagos. Pp. 53-100.

Fashakin, J. B. and Fasanya, J. I. (1988). Chemical composition and nutritive changes of some

improved varieties of cowpea (Vigna unguiculata L.): some selected varieties from IITA, Ibadan, Nigeria Tropical Science. 28: $111-118$.

Fashakin, J. B. and Ojo, F. A. (1988). Chemical composition and nutritive changes of some improved varieties of cowpea (Vigna unguiculata (L.) Walp 2: new breeds of varieties from the IITA Ibadan, Nigeria. Tropical Science 28: 191- 199. 
FAO (2002). World Agriculture: towards 2015/2030. Summary report, Rome.

FMANR (1990). Literature on soil fertility investigation in Nigeria. A bulletin produced by the Federal Ministry of Agriculture and Natural Resources, Lagos. 40p.

Islam, S., Cowmen, R.C. and Ganer, J. O. (2006). Screening for tolerance of stress temperature during germination of twenty-five cowpea (Vigna unguiculata L. Walp) cultivars. Journal of Food, Agriculture and Environment 4(2): 189191.

Muoneke, C. O., Ndukwe, O.M., Umana, P.E., Okpara, D.A. and Asawalam, D. O. (2012). Productivity of vegetables cowpea (Vigna unguiculata L. Walp) and maize (Zea mays L.) intercropping system as influenced by component density in a tropical zone of southeastern Nigeria International Journal of Agricultural Research and Development 15 (1):835-847.

Ofuya, A. K. (1993). Evaluation of selected cowpea varieties for resistance to Aphis caccivora Koch. (Homophera: Aphididae) at the seedling and pod stage. Annals

Ogbo, E. M. (2009). Effects of diesel fuel contamination on seed germination of four crop plants-Arachis hypogaea, Vignia unguiculata Sorghum bicolor and Zea mays. African Journal of Biotechnology 8(20: 250-253.

Owolade, O. F., Akande, M. O. Alabi, B. S. and Adediran, J. A. (2006). Phosphorus level effects on brown blotch disease, development and yield of cowpea. World Journal of Agricultural Science 2(1): 105108.

Philip, R. D. and McWatters, K. H. (1991). Contribution of cowpea to nutrition and health. Food Technology 9: 127 - 130.

Platt, B. S. (1962). Tables of representative value of foods commonly used in tropical countries Med. Res. Counc. Special edition report series No. 302, London.

Rachie, K. O., Singh, S. R. and Rachie, S. K. (1985). Introduction to cowpea research, production and utilization

Reminson, S. U., Bello, B. and Okunarin, T. (1980). The effects of different spacing and phosphorus application on the growth and yield of cowpea Ife Journal of

Agriculture. 2: 67 - 73. Sankie, L., Addo-Bediako, K. O. and Ayodele, V. (2012). Susceptibility of seven cowpea (Vigna unguiculata L. Walp) cultivars to cowpea beetle (Callosbruchus maculatres) Agricultural Science Research Journals 2(2):65-69.

SAS (2005). SAS User's guide statistics version 5, SAS Institute Inc. Raleigh, New York. U.S.A. 
Shiringani, R.P. and Shimeles, H. A. (2011). Yield response and stability among cowpea genotypes at three planting dates and test environments. African Journal of Agricultural Resources 6(4): 3259-3263.

Singh, S. R. and Rachie, K. O. (1985). Cowpea research and utilization. John Wiley and Sons, New York.400p.

Verma, J. S. and Mishra, S. N. (1989). Evaluation of improved cowpea lines from IITA in humid subtropical. Indian Tropical Grain Legume Bulletin 36: 38 - 39. 